\title{
Endoparasitic helminths of water frog complex in Poland: do differences exist between the parental species Pelophylax ridibundus and Pelophylax lessonae, and their natural hybrid Pelophylax esculentus?
}

\author{
M. POPIOŁEK ${ }^{1}$, B. ROZENBLUT-KOŚCISTY ${ }^{2}$, M. KOT ${ }^{1}$, W. NOSAL ${ }^{2}$, M. OGIELSKA ${ }^{2}$ \\ ${ }^{1}$ Department of Invertebrate Systematics and Ecology, Institute of Biology, Wrocław University of Environmental and \\ Life Sciences, Kożuchowska 5b, 51-631 Wrocław, Poland, E-mail: marcin.popiolek@up.wroc.pl; \\ ${ }^{2}$ Department of Biology and Conservation of Vertebrates, Zoological Institute, University of Wrocław, \\ ul. Sienkiewicza 21, 50-335 Wrocław, Poland
}

\begin{abstract}
Summary
Parasitic fauna of water frogs was mainly studied in the second half of the 20th century. However, these studies were done without differentiation into species and hybrids and pooled the 3 taxa as "water frogs" or "green frogs". The aim of this study was to make an inventory of helminth species as well as their prevalence and intensity of infection in the two parental species (Pelophylax ridibun$d u$ and $P$. lessonae) and the hybrid (P. esculentus) of water frogs from 3 big populations composed of hundreds or thousands of individuals inhabited natural and seminatural landscapes in Poland. Eight helminth species were found: Polystoma integerrimum, Diplodiscus subclavatus, Opisthoglyphe ranae, Gorgodera cygnoides, Haematoloechus variegatus, Oswaldocruzia filiformis, Cosmocerca ornata and Acanthocephalus ranae. The results were compared with data from other, polish and European studies. Additionally we compared the level of infection among water frog taxa.
\end{abstract}

Keywords: helminth parasites; green frogs complex; Pelophylax ridibundus; Pelophylax lessonae; Pelophylax esculentus; Poland

\section{Introduction}

Parasitic fauna of water frogs was mainly studied in the second half of the 20th century (Combes, 1972; Combes \& Sarrouy, 1971; Odening, 1955 - 56, 1957; Vojtkova, 1974, 1975; Vojtkova \& Vojtek, 1975; Cedhagen, 1988; Fernandez, 1984; Galeano et al., 1990). A review of helminthfauna of frogs and toads of Europe was published by Vojtkova \& Roca $(1993,1994,1996)$. In Poland the research were carried out by Sander (1949), Grossman \& Sandner (1954), Grabda-Kazubska (1972a,b, 1978, 1980, 2000), Kozłowska (1960), Plasota (1969), Kuc \& Sulgostowska 1988a,b), and Pilecka-Rapacz (1997, 1998). However, these studies were done without differentiation into the species and hybrids and pooled the 3 taxa as "water frogs" or "green frogs". For this reason and due to rapidly changing environment and increasing decline of amphibian populations, the information about water frog parasites should be updated (Pojmańska et al., 2007). Furthermore, the assignment of the species composition of parasitic fauna to host species is also important from the verification of host specificity point of view.

The taxonomy of water frogs changed over time (Berger, 1969, 1983). Before 1959 all European taxa were named Rana esculenta after Linne (1758). Then $R$.. ridibunda was described as a separate species, whereas $R$. lessonae was described as a subspecies or a geographical form of $R$.. esculenta owing to their morphological similarity. Finally in 1967 Berger revealed that $R$. esculenta is a natural hybrid between $R$. ridibunda and $R$. lessonae (for review see Graf \& Polls-Pelaz, 1989). Now the name of the genus has been changed into Pelophylax (Frost, 2009).

Water frog complex in Europe is composed of 3 taxa: two species Pelophylax lessonae (formerly Rana lessonae Camerano, 1882) and $P$. ridibundus (formerly $R$. ridibunda Pallas, 1771), and their hybridogenetic hybrid P. esculentus (formerly $R$. esculenta L.). All three taxa are very closely related and can mate and give progeny. $P$. ridibun$d u s$ inhabits and hibernate in rivers, lakes and big fish ponds with running water; $P$. lessonae lives in small ponds and hibernates on land, whereas $P$. esculentus inhabits all types of water bodies and hibernates either in water or on land. In the wild they form mixed populations (L-E, lessonae-esculentus and R-E, ridibundus-esculentus) according to their ecological preferences; in rare cases all three taxa live together in the same locality (L-E-R, lessonaeesculentus-ridibundus) (for review see Berger, 1966; Rybacki \& Berger 2001; Plötner, 2005).

The aim of this study was to make an inventory of helminth species, as well as their prevalence and intensity of infection in two parental species ( $P$. ridibundus and $P$. 
lessonae) and the hybrid (P. esculentus) of water frogs from 3 big populations composed of hundreds or thousands of individuals inhabited natural and semi-natural landscapes in Poland. For this reason studies performed by us may serve as references for those carried out on water frog populations inhabiting areas with higher human impact or facing other environmental difficulties. We also focused on genetic and environmental differences in susceptibility of infection between the water frog taxa.

\section{Material and methods}

Study area

(1.) Słowiński National Park (SNP), of total area of 18247 ha, is situated at the southern shore of the Baltic Sea. It is composed of the system of small rivers, shallow seaside lakes, bogs, peat bogs, meadows, forests, and moving dunes. The frogs ( $P$. esculentus, $P$. lessonae and $P$. ridibundus) were collected in the south-east part of the Gardno Lake (N 5440', E 178') with temporarily occurring slightly brackish waters and along the shores of the

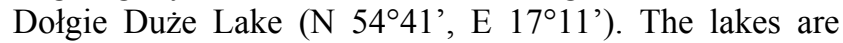
eutrophic with great diversity of water plants. The invertebrate fauna of the Gardno Lake was described by Guttowa (1958) and Strzelecki and Półtorak (1971).

(2.) Nadmorski Landscape Park (NLP) of total area of 18804 ha $(39.6 \%$ of land along the seashore and $60.4 \%$ of the Gulf of Puck). The frogs ( $P$. esculentus and P. lessonae) were collected in two nature reserves: Bielawa peat

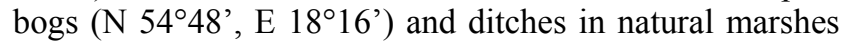
of the Mechelińskie Ląki located at the Gulf shore (N 543', E 18³0').

(3.) Landscape Park of the Barycz River Valley (BRV) of total area of 87040 ha in south-west Poland. Frogs were collected in the water bird reserve "Milicz Ponds" that is composed of forests, fields, meadows and various fish ponds (about $65 \%$ of the area). The reserve is composed of 5 fishpond complexes composed of approximately 100 ponds with a total area of $77 \mathrm{~km}^{2}$. It is one of the most valuable regions in Europe with high biodiversity and water management system that has been almost unchanged since the Middle Ages. The frogs ( $P$. esculentus and $P$. ridibundus) were collected in two complexes: Stawno (N 51 $32^{\prime}$, E $17^{\circ} 21^{\prime}$ ) and Potasznia (N 51 32 ', E 17²9'). The invertebrate fauna in the region is rich, but not well studied.

\section{Hosts identification}

We analyzed 733 randomly selected adults of both sexes collected in 2001 and 2002 from water bodies inhabited by mixed populations of water frog taxa ( $P$. esculentus/P. lessonae and $P$. esculentus/P. ridibundus, respectively). The frogs analysed in this study were also used in several other projects (e.g. Ogielska et al., 2004; Socha \& Ogielska, 2010). The localities and numbers of animals in the samples are summarized in Table 1. The sex was identified according to external characters. For taxonomical identification of frogs we used 4 morphometric characters: snout-vent length (SVL), tibia length (T), first toe length (DP - digitus primus) and callus internus length (CI). Two biometrical indices $\mathrm{DP} / \mathrm{CI}$ and $\mathrm{T} / \mathrm{CI}$, traditionally used in taxonomy of East European water frogs (Berger, 1966; Plötner, 2005), were calculated. All frogs were measured with a calliper to the nearest $0.01 \mathrm{~mm}$. To support morphometric analysis, the specimens were additionally checked by chromosome analysis on metaphase plates stained with actinomycine D/ DAPI according to Ogielska et al. (2004).

\section{Parasitological dissection}

The specimens were subjected to the standard method for helminthological dissection (Niewiadomska, 2003). The parasites were rinsed by physiological salt solution, counted and conserved in $70 \%$ ethanol. Fixed trematodes and acanthocephalans were stained with borax carmine and differentiated by acid ethanol, dehydrated in series of ethanol, cleared in carnation oil and mounted on slides in the Canada balsam. Nematodes were cleared in glycerol. The prevalence and mean intensity of infection were calculated according to Bush et al. (1997).

\section{Statistical analysis}

To show the possible differentiation between an intensity of infection of water frog taxa and between the studied sites we applied the Chi-square test, and the nonparametric tests of Mann-Whitney and Kruskal-Wallis. The normality of distributions of analyzed variables was verified with the Shapiro-Wilk test. Statistical analyses were performed at $p$ $\leq 0.05$, with the use of statistical software package Statistica (version 9.0 PL).

Table 1. Sample sizes and localities of collection of three water frog taxa

\begin{tabular}{lcccc}
\hline \multirow{2}{*}{ Host } & \multicolumn{3}{c}{ Site of collection } & \multirow{2}{*}{ Total } \\
\cline { 2 - 4 } & $\begin{array}{c}\text { Slowiński } \\
\text { National Park }\end{array}$ & $\begin{array}{c}\text { Nadmorski } \\
\text { Landscape Park }\end{array}$ & $\begin{array}{c}\text { Barycz } \\
\text { River Valley }\end{array}$ \\
\hline Pelophylax esculentus & 148 & 25 & 116 & 289 \\
Pelophylax lessonae & 13 & 68 & -- & 81 \\
Pelophylax ridibundus & 13 & -- & 350 & 363 \\
Total & $\mathbf{1 7 4}$ & $\mathbf{9 3}$ & $\mathbf{4 6 6}$ & $\mathbf{7 3 3}$ \\
\hline
\end{tabular}




\section{Results}

Review of species

The helminth fauna of water frogs from the 3 localities was represented by 8 species belonging to Monogenea, Digenea, Nematoda and Acanthocephala (Tab. 2). The list of species together with short comments concerning already existing data is provided below.

\section{MONOGENEA}

Polystoma integerrimum (Froelich, 1791)

Host: Pelophylax esculentus.

Site of location: urinary bladder.

Locality, prevalence and mean intensity of infection (range): SNP: $4.0 \% ; 2.5$ (from 1 to 5 individuals).

Comments: Polystoma integerrimum is the monogenic parasite of amphibians and was found in Bufo viridis and typically in Rana arvalis and $R$. temporaria where its prevalence was respectively $5.5 \%$ and $10.5 \%$ in Warszawa (Sandner, 1949), $14.4 \%$ and $10.9 \%$ in Wrocław and Barycz River Valley (Paul, 1934), and $12 \%$ and $3 \%$ in Łódź (Szulc, 1962). Madel (1983) reported its presence in Germany and Vojtkova (1989) in the Czech Republic. Although Polystoma integerrimum was also described in water frogs by Dawes (1946), André (1912, 1913), Layman (1933) and Grossman and Sandner (1954) doubted whether it was possible.

\section{DIGENEA}

Gorgodera cygnoides (Zeder, 1800)

Hosts: Pelophylax esculentus, P. lessonae, P. ridibundus. Site of location: urinary bladder.

Locality, prevalence and mean intensity of infection (range): SNP: P. esculentus $5.4 \%, 2.1(1-5)$; NLP: P. lessonae $4.4 \%, 1.7$ ( $1-3)$; BRV: P. ridibundus $0.3 \%, 7$ (7).

Comments: $G$. cygnoides is a common parasite species of anuran amphibians in Poland (Grabda-Kazubska, 1972a, Kuc \& Sulgostowska, 1988a,b). The prevalence values reported for water frogs from other localities at the Baltic Sea shore (5.9\%, Grossman-Pojmańska \& Sandner, 1958) were similar to ours in NLP and SNP, but lower than in other localities in Poland: the Białowieski NP (15\%, Grossman \& Sandner, 1954), the Lódź region (21\%, Szulc, 1962), the Warszawa region (27\%, Sinicyn, 1905), and very high values from Wrocław and Lower Silesia (33 $-65 \%$, Sander, 1949 and $22 \%$, Paul, 1934).

\section{Diplodiscus subclavatus (Pallas, 1760)}

Hosts: Pelophylax esculentus, P. lessonae, P. ridibundus. Site of location: distal portion of small intestine and large intestine.

Locality, prevalence and mean intensity of infection (range): NLP: P. esculentus $4.0 \%, 2.0$ (2), P. lessonae $1.5 \%$, 1.0 (1); BRV: P. ridibundus $0.3 \%, 1.0$ (1).

Table 2. Prevalence and intensity of infection of helminths in water frog host taxa at the studied sites

\begin{tabular}{|c|c|c|c|c|c|c|c|c|c|c|}
\hline Locality & Host & 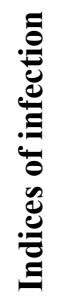 & 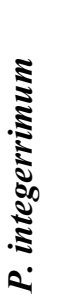 & 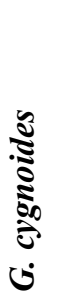 & 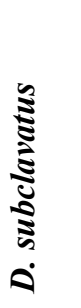 & 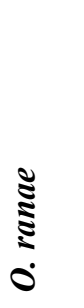 & 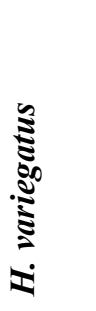 & 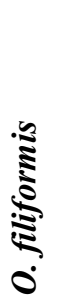 & 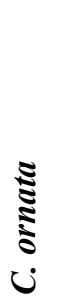 & 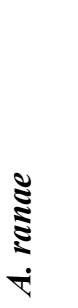 \\
\hline \multirow{6}{*}{$\begin{array}{l}\text { Słowiński } \\
\text { National Park } \\
\text { (SNP) }\end{array}$} & \multirow{2}{*}{ P. esculentus } & $(\%)$ & 4.0 & 5.4 & -- & -- & 20.3 & 1.4 & 2.7 & 8.9 \\
\hline & & int. & 2.5 & 2.1 & -- & -- & 5.7 & 1.0 & 1.3 & 1.3 \\
\hline & \multirow{2}{*}{ P. lessonae } & $(\%)$ & -- & -- & -- & -- & 15.4 & -- & -- & 7.7 \\
\hline & & int. & -- & -- & -- & -- & 2.5 & -- & -- & 1.0 \\
\hline & \multirow{2}{*}{ P. ridibundus } & $(\%)$ & -- & -- & -- & -- & 7.7 & -- & -- & 15.4 \\
\hline & & int. & -- & -- & -- & -- & 1.0 & -- & -- & 1.0 \\
\hline \multirow[b]{2}{*}{ Nadmorski } & \multirow{2}{*}{ P. esculentus } & $(\%)$ & -- & -- & 4.0 & 4.0 & 20.0 & 4.0 & -- & 24.0 \\
\hline & & int. & -- & -- & 2.0 & 2.0 & 2.4 & 3.0 & -- & 2.5 \\
\hline \multirow{3}{*}{$\begin{array}{l}\text { Landscape } \\
\text { Park (NLP) }\end{array}$} & \multirow{2}{*}{ P. lessonae } & $(\%)$ & -- & 4.4 & 1.5 & 4.4 & 13.2 & 7.4 & 4.4 & 26.5 \\
\hline & & int. & -- & 1.7 & 1.0 & 5.3 & 2.4 & 1.6 & 1.7 & 1.2 \\
\hline & P. ridibundus & -- & -- & -- & -- & -- & -- & -- & -- & -- \\
\hline \multirow{5}{*}{$\begin{array}{l}\text { Barycz River } \\
\text { Valley (BRV) }\end{array}$} & \multirow{2}{*}{ P. esculentus } & $(\%)$ & -- & -- & -- & 0.9 & -- & 0.9 & -- & 0.9 \\
\hline & & int. & -- & -- & -- & 1.0 & -- & 1.0 & -- & 1.0 \\
\hline & \multirow[t]{2}{*}{ P. lessonae } & -- & -- & -- & -- & -- & -- & -- & -- & -- \\
\hline & & $(\%)$ & -- & 0.3 & 0.3 & -- & 0.6 & 0.3 & -- & 1.1 \\
\hline & P. ridibundus & int. & -- & 7.0 & 1.0 & -- & 3.5 & 3.0 & -- & 5.3 \\
\hline
\end{tabular}

Abbreviations: (\%) - prevalence; int. - mean intensity of infection 
Comments: Diplodiscus subclavatus was the rarest species recorded in our study although it was usually reported as a common one. Grossman-Pojmańska \& Sandner (1958) noted it in $52.8 \%$, Szulc (1962) in $22.4 \%$, Sinicyn (1905) in $17.4 \%$, and Plasota (1969) in $100 \%$ individuals. Sandner (1949) recorded it in $10-33 \%$ and Paul (1934) in $50 \%$ infected water frogs in Lower Silesia, whereas we found none in the Barycz River Valley. D. subclavatus is a common parasite species of amphibians in Poland, both anuran (Grabda-Kazubska, 1972a; Kuc \& Sulgostowska, 1988a,b; Grabda-Kazubska \& Lewin, 1989; PileckaRapacz, 1998) and newts (Bertman, 1994), as well as in other European countries (Vojtkova \& Roca 1994; Düşen \& Öz, 2006). It was also recorded in reptiles: Lacerta agilis (Lewin, 1992), Natrix natrix (Bertman, 1993) and Vipera berus (Lewin \& Grabda-Kazubska, 1997).

\section{Opisthioglyphe ranae (Froelich, 1791)}

Hosts: Pelophylax esculentus, P. lessonae.

Site of location: small intestine.

Locality, prevalence and mean intensity of infection (range): NLP: P. esculentus $4.0 \%, 2.0$ (2), P. lessonae $4.4 \%$, 5.3 (2 - 12); BRV P. esculentus $0.9 \%, 1.0$ (1).

Comments: Opisthioglyphe ranae was a rare species in our sample although its prevalence is usually high in water frogs: $36 \%$ in the Białowieski NP (Grossmann \& Sandner, 1954); $51.3 \%$ in the Łódź region (Szulc, 1962); 78.2\% in the Kampinoski NP (Kuc \& Sulgostowska, 1988b); $82.8 \%$ in Mazury (Grabda-Kazubska, 1972a), and $57.5 \%$ in the Barycz River Valley (Paul, 1934). Sandner (1949) recorded it in $65 \%$, and Kuc \& Sulgostowska (1988a) in $83.9 \%$ of $P$. ridibundus whereas we did not found it any individual of this taxon. O. ranae is one of the most common trematodes in amphibians of Poland, as well as in Natrix natrix (Grabda-Kazubska, 1972a; Kuc \& Sulgostowska, 1988a,b; Pilecka-Rapacz, 1998).

\section{Haematoloechus variegatus (Rudolphi, 1819)}

Hosts: Pelophylax esculentus, P. lessonae, P. ridibundus. Site of location: lungs.

Locality, prevalence and mean intensity of infection (range): SNP: P. esculentus $20.3 \%, 5.7(1-25)$, P. lessonae $15.4 \%, 2.5$ (2-3), P. ridibundus $7.7 \%, 1.0$ (1); NLP: $P$. esculentus $20.0 \%, 2.4(1-4)$, P. lessonae $13.2 \%, 2.4(1-$ 6); BRV: P. ridibundus $0.6 \%, 3.5(2-5)$.

Comments: $P$. ridibundus was the less infected species in our sample, as was also reported by Kuc \& Sulgostowska (1988a) in the same host species $(1.4 \%)$. We also noted very low infection in $P$. ridibundus from the Barycz River Valley, although Paul (1934) recorded much higher prelevance of $H$. variegatus $(27.9 \%)$ in 68 water frogs from the same region. $H$. variegatus is a common parasite of amphibians in Poland (Grabda-Kazubska, 1972a; Kuc \& Sulgostowska, 1988a,b) and was the most prevalent and of the highest infection intensity (1-25) also in our sample. In water frogs in Poland it was recorded in the Kampinoski NP (prevalence $11.4 \%$ according to Plasota, 1969), environs of Warsaw (prevalence $35.6 \%$ according to Kuc \&
Sulgostowska, 1988b), the Łódź region (prevalence $14.9 \%$ according to Szulc, 1962), and Białowieski NP (prevalence $9 \%$ according to Grossman \& Sandner, 1954).

\section{NEMATODA}

Oswaldocruzia filiformis (Goeze, 1782)

Hosts: Pelophylax esculentus, $P$. lessonae, P. ridibundus. Site of location: small intestine.

Locality, prevalence and mean intensity of infection (range): SNP: P. esculentus $1.4 \%, 1.0$ (1); NLP: $P$. esculentus $4.0 \%$, 3.0 (3), P. lessonae $7.4 \%, 1.6(1-2)$; BRV: P. esculentus $0.9 \%, 1.0$ (1), P. ridibundus $0.3 \%, 3.0$ (3).

Comments: $O$. filiformis is not a common nematode species in water frogs and was formerly noted only in the Łódź region by Kozłowska (1960) and in Lower Silesia by Paul (1934). So far O. filiformis was described in P. esculentus and $P$. lessonae, but not in $P$. ridibundus (Pojmańska et al., 2007) in Poland. However, we recorded this species in all 3 taxa of water frogs, similarly to Vojtkova \& Roca (1994). O. filiformis is found in other amphibian species in Poland, typically in Bufo bufo (Grabda-Kazubska, 1972a), but accidentally also in fishes, as in Salmo trutta m. fario (Popiołek et al., 2004). It was also recorded in reptiles: Anguis fragilis (Düşen et al., 2010) in Turkey.

\section{Cosmocerca ornata (Dujardin, 1845)}

Hosts: Pelophylax esculentus, P. lessonae.

Site of location: distal portion of small intestine and large intestine.

Locality, prevalence and mean intensity of infection (range): SPN: P. esculentus $2.7 \%, 1.3(1-2)$; NLP: $P$. lessonae $4.4 \%, 1.7(1-2)$.

Comments: In our sample Cosmocerca ornata was recorded for the first time in P. lessonae in Poland. C. ornata was reported in the Łódź region (prevalence $20.7 \%$ ) and Turew (35.5\%) by Kozłowska (1960), and in the Kampinoski NP (23\%, Kuc \& Sulgostowska, 1988b). C. ornata was not reported in the Barycz River Valley neither by us nor by Paul (1935). C. ornata is a common parasite of amphibians in Poland, typically in Rana teporaria (Grabda-Kazubska, 1972a; Kuc \& Sulgostowska, 1988b; Grabda-Kazubska \& Lewin, 1989), also recorded in Vipera berus (Lewin \& Grabda-Kazubska, 1997). It was also recorded in reptiles: Anguis fragilis (Düşen et al., 2010) in Turkey.

\section{ACANTHOCEPHALA}

\section{Acanthocephalus ranae (Schrank, 1788)}

Hosts: Pelophylax esculentus, P. lessonae, P. ridibundus. Site of location: small intestine.

Locality, prevalence and mean intensity of infection (range): SNP: P. esculentus $8.9 \%, 1.3(1-3)$, P. lessonae 7.7 \%, 1.0 (1), P. ridibundus 15,4 \%, 1.0 (1); NLP: $P$. esculentus $24.0 \%, 2.5(1-5)$, P. lessonae $26.5 \%, 1.2(1-$ 2); BRV: P. esculentus $0.9 \%, 1.0$ (1), P. ridibundus $1.1 \%$, $5.3(1-16)$.

Comments: A. ranae was a common species in our sample 
and was noted in the 3 frog taxa from all localities. According to Kuc \& Sulgostowska (1988a), $69.7 \%$. ridibundus individuals were infected, whereas in our study we recorded prevalence $15.4 \%$ for the same species in the Słowiński NP. Sandner (1949) reported from 16 to $59 \%$, and Paul (1934) in $23.5 \%$ infected water frogs. A. ranae is known from all frog species in Poland. Styczyńska (1958) noted it in $50 \%$ water frogs from the Drużno Lake, Plasota (1969) from $4.5 \%$ in the Kampinoski NP, and Grossman \& Sandner (1954) in $11 \%$ from the Białowieski NP. $A$. ranae is a common parasite of amphibians in Poland (Grabda-Kazubska, 1972a; Kuc \& Sulgostowska, 1988b) and other localities in Europe (Vojtkova \& Roca, 1996; Düşen \& Öz, 2004, 2006; Düşen, 2007; Düşen et al., 2009; Düşen \& Oğuz, 2010; Düşen, 2011). It was rarely recorded in a duck Anas platyrhynchos (Sulgostowska, 1997) and in Vipera berus (Lewin \& Grabda-Kazubska, 1997).

Comparison of prevalence of infection between water frog taxa

General prevalence of infection differed among the studied taxa. Pelophylax lessonae was the most infected species ( $55.5 \%$ out of 81 individuals), $P$. esculentus was infected in $27.7 \%$ (out of 289 individuals), and $P$. ridibundus was the less infected species (3.3\% out of 365 individuals).

Pelophylax esculentus was the only taxon that shared the same populations with the other 2 taxa ( $P$. lessonae and/or $P$. ridibundus $)$ in all localities and therefore we were able to compare infection in relation to co-existing parental species under the same environmental conditions. The highest prevalences (44.0\%; mean infection intensity: 2.4 ) were recorded in $P$. esculentus from L-E (lessonaeesculentus) mixed population in the Nadmorski Landscape Park (NLP) and from L-E-R (lessonae-esculentusridibundus) mixed population (35.1\%; mean infection intensity: 4.2) in the Słowiński National Park (SNP). The lowest values (2.6\%, mean infection intensity: 3.0) was noted in the Barycz River Valley (BRV). The differences were statistically important $\left(\chi^{2}=51.8 ; \mathrm{d}=2 ; \mathrm{p}=0.000\right)$. The diversity of helminths also differ: we found 6 species $(P$. integerrimum, G. cygnoides, $H$. variegatus, O. filiformis, $C$. ornata) in L-E-R population from SNP, 5 species $(O$. ranae, $D$. subclavatus, $H$. variegatus, $O$. filiformis, $A$. ranae) in L-E from NLP, and only 2 species ( $H$. variegatus, $A$. ranae) in R-E (ridibundus-esculentus) population in BRV. Two species (O. filiformis, A. ranae) were found in $P$. esculentus from all types of populations, but we noticed differences in prevalences only for $A$. ranae. The highest prevalence $(24 \%)$ was recorded in L-E from NLP, then $8.9 \%$ in L-E-R from SNP, whereas the lowest $(0.9 \%)$ was noted in R-E from BRV $\left(\chi^{2}=44.02\right.$; $\mathrm{d}=2 ; \mathrm{p}=0.000)$. Similarly, intensity of infection was the highest in L-E and the lowest in R-E (Kruskal-Wallis test: $\mathrm{H}=45.2 ; \mathrm{p}=0.000)$.

Pelophylax lessonae individuals were collected at the Baltic Sea shore from 2 regions localized about $80 \mathrm{~km}$ apart. The prevalence of infection was higher in the NLP than in the SPN (44.0\% vs. $30.8 \%$ ), but the difference was not statistically important. However, there was a great difference in number of helminth species that infected $P$. lessonae from the two localities. We noticed 6 species in NPK (G. cygnoides, D. subclavatus, H. variegatus, O. filiformis, C. ornata, A. ranae) and only 2 species in SNP (H. variegatus and $A$. ranae). The prevalences of $H$. variegates were similar in both localities (NLP: $13.3 \%$; 2.4 vs. SNP: $15.4 ; 2.5)$, whereas the prevalence of $A$. ranae was higher in NLP than in SNP $(26.5 \% v s .7 .7 \%)$, but not statistically important $\left(\chi^{2}=2.14 ; \mathrm{d}=1 ; \mathrm{p}=0.143\right)$.

Pelophylax ridibundus - the third species of the analyzed frogs was found only in locality of SPN and BRV. Because of significant differences in sample sizes from both localities, a comparison of the level of infection may be burdened with some error. Since, however, in the case of $P$. ridibundus, sample size is also a reflection of the occurrence frequency of this species in these two very different environments, it was decided to show the basic parasitological indicators. The overall prevalence of infection in $P$. ridibundus SPN was higher than in the BRV (21.1\% vs. $4.6 \%$ ), while the average value of intensity was as vice versa (SPN vs. 1.0. BRV 2.1). In the SPN was recorded only two species of parasites $(H$. variegatus and A. ranae), while in frogs of BRV as many as five ( $G$. cygnoides, D. subclavatus, $H$. variegatus, $O$. filiformis and A. ranae). Prevalence of infection of individual helminths species (including two occurring in both places) proved to be significantly higher in SNP than in the BRV.

The only locality where we were able to analyze an environmental impact on susceptibility of the three water frog taxa to helminth infection was the L-E-R population in SPN. Both prevalence and intensity of infection were similar for $P$. esculentus and P. lessonae $(35.1 \%$ and 4.2 vs. $30.8 \%$ and 3.0$)$ and lower for $P$. ridibundus $(23.1 \%$ and 1.0). P. esculentus individuals were invaded by six helminth species ( $G$. cygnoides, $D$. subclavatus, $H$. variegatus, $O$. filiformis, C. ornata, A. ranae), whereas $P$. lessonae and $P$. ridibundus only by two ( $H$. variegatus and A. ranae). We particularly focused on $P$. esculentus individuals collected in high numbers from two sites within SNP (Gardno and Dołgie Duże lakes), but we did not found differences in prevalences and intensities of infection between them when tested by $\chi^{2}$. The composition of helminth species hosted by P. esculentus from the Gardno and Dołgie Duże lakes did not differ as well.

\section{Discussion}

The helmintofauna of water frogs from the three localities studied by us was rather poor and not numerous (Tab. 2) and was represented by 8 species, out of 48 described so far in water frogs from Poland (Grabda-Kazubska, 1972a). However, this information does not tell us about differences among the two parental species (Pelophylax ridibundus and $P$. lessonae) and hybrids ( $P$. esculentus), because it pools all the water frog taxa together.

The most interesting question in our study is whether 
prevalences, infection intensities and diversity of parasite species differ in relation to localities (environment) or water frog taxa (genetics). A good example comes from a comparison between two different sites: Nadmorski Landscape Park (NLP) and the Barycz River Valley (BRV). In NLP the values of prevalence, infection intensities and diversity of helminth species were high for the parental species $P$. lessonae and the hybrid $P$. esculentus. On the other hand, the extremely low values for the parental species $P$. ridibundus and the hybrid were recorded in BRV, most probably owing to procedures used in the carp culture, where one of the cyclic procedures from at least several decades has been manuring with lime that certainly influence the diversity and quantity of the plankton and benthos invertebrate fauna, and thereby can eliminate some of the intermediate hosts of the helminth species.

We do not observe such a clear effect of genetics of particular water frog taxa for susceptibility of helminth infection. An environmental influence may be ruled out only in the Słowiński National Park (SNP), where the two parental species and the hybrid inhabit the same sites. However, we observed only slight differences in intensities of infection among the taxa, although the hybrid $P$. esculentus seems to be more exposed probably as a result of a higher migratory activity in comparison to the parental species (Berger, 1983).

These two data sets show that the influence of environmental cues on the helminth infection of water frogs is out of question, whereas their genetics is only slightly involved.

\section{Acknowledgements}

We would like to thank Małgorzata Socha, Renata Augustyńska and Piotr Kierzkowski for their help in field work and collection of material. Polish Ministry of Environment Protection and Forestry for performing studies on protected species OP 4072/218 /96; OP 4072/218/98/4501; OP 4201/144/99, and II Local Commission for Ethics in Experiments on Animals 13/02. The study was financed by the State Committee for Scientific Research, Poland, project No. 6P04C 06119 and University of Wrocław, Poland, DS/IZ/2010.

\section{References}

ANDRÉ, E. (1912): Recherches parasitologiques sur les amphibians de la Suisse. Rev. Suis. Zool., 20: $471-485$

ANDRÉ, E. (1913): Recherches parasitologiques sur les amphibians de la Suisse. II. Rev. Suis. Zool., 21: $179-200$

BERGER, L. (1966): Biometrical studies on the population of green frogs from the environs of Poznań. Ann. Zool., 23: $303-324$

BERGER, L. (1969): Systematics of forms within Rana esulenta complex. Przegl. Zool., 12: 219-238

BERGER, L. (1983): Western palearctic frogs (Amphibia, Ranidae): systematics, genetics and population composi- tion. Experientia, 39: 127 - 130

Bertman, M. (1993): Diplodiscus subclavatus (Pallas, 1760) (Trematoda) and Acanthocephalus ranae (Schrank, 1788) (Acanthocephala) in grass snake - Natrix natrix (L.). Wiadom. Parazyt., 39: 405 - 406

Bertman, M. (1994): Parasites of the smooth newt Triturus vulgaris L. and the crested newt - Triturus cristatus (Laur) of the Tarnobrzeg voivodship. Wiadom. Parazyt., 40: 93 - 97

Busch, A., Lafferty, K. D., Lotz, J. M., Shostak, A. W. (1997): Parasitology meets ecology on its own terms: Margolis et al. revisited. J. Parasitol., 83: 575 - 583. DOI: $10.2307 / 3284227$

Cedhagen, T. (1988): Endoparasites in some Swedish amphibians. Acta Parasitol. Polon., 33: $107-113$

COMBES, C. (1972): Influence of the behaviors of amphibians on the helminth life cycles. Zool. J. Lin. Soc., 51: 151 $-170$

Combes, C., SArrouy, H. (1971): Helminthes de Rana ridibunda perezi (Amphibia) dans la region de Soria. Rev. Iber. Parasitol., 31: $115-119$

DAWES, B. (1946): The Trematoda. University Press, Cambridge, U.K., pp. 644.

DüşEN, S., Öz, M. (2004): Helminth parasites of the Tree Frog, Hyla arborea (Anura: Hylidae) from Southwest Turkey. Comp. Parasitol., 71 (2): 258 - 261. DOI: $10.1654 / 4123$

DüşEN, S., Öz, M. (2006): Parasitic helminths of the Marsh Frog, Rana ridibunda Pallas, 1771 (Anura: Ranidae), from Antalya Province, south-west Turkey. Comp. Parasitol., 73 (1): 121 - 129. DOI: $10.1654 / 4162.1$

DÜŞEN, S. (2007): Helminths of the two Mountain Frogs, Banded Frog, Rana camerani Boulenger, 1886 and Uludağ Frog Rana macrocnemis Boulenger, 1885 (Anura: Ranidae), collected from Antalya Province. Acta Parasitol. Tur., 31 (1): $84-88$

Düşen, S., UĞUrtaş, İ. H., AydoĞdu, A., OĞUz, M. C. (2009): The helminth community of the Agile frog, Rana dalmatina Bonaparte, 1839 (Anura: Ranidae) Collected from Nortwest of Turkey. Helminthologia, 46 (3): 177 182. DOI: $10.2478 / \mathrm{s} 11687-009-0033-8$

DÜşen, S., UĞURTAŞ, İ. H., AYdOĞDU, A. (2010): Nematode Parasites of the Two Limbless Lizards: Turkish Worm Lizard, Blanus strauchi (Bedriaga, 1884) (Squamata: Amphisbaenidae) and Slow Worm, Anguis fragilis Linnaeus 1758 (Squamata: Anguidae), from Turkey. Helminthologia, 47 (3): 158 - 163. DOI: 10.2478/s11687-010-0024-9

DÜŞEN, S., OĞUZ, M. C. (2010): Metazoan endoparasites of three species of anurans collected from the middle Black Sea region of Turkey. Helminthologia, 47 (4): 226 - 232. DOI: $10.2478 / \mathrm{s} 11687-010-0035-6$

DÜŞEN, S. (2011): First data on helminthfauna of the locally distributed a mountain frog, "Tavas Frog", Rana tavasensis Baran and Atatür, 1986 (Anura: Ranidae), from Inner-West Anatolia Region, Turkey. Turk. J. Zool. DOI: 10.3906/zoo-0909

FernandeZ, J. P. (1984): Contribución al estudio de la helmintofauna del género Bufo. Tesis de Licenciatura, 
Facultad de Biología, Universidad de Valencia, pp. 131. Frost, D. R. (2009): Amphibian species of the world: an online reference. Version 5.3 (12 February, 2009). American Museum of Natural History, New York, USA. Electronic database accessible at http://research.amnh.org/vz/ herpetology/amphibia/

Galeano, M, Nawarro, P., Lluch, J. (1990): Helmintofauna de Hyla spp. (Amphibia: Hylidae) en algunas localidades epsañolas. Misc. Zool., 14: $1-6$

GRABDA-KAZUBSKA, B. (1972a): Catalogue of parasite fauna of Poland. III. Parasites of amphibian and reptilies. Państwowe Wydawnictwo Naukowe, Warszawa-Wrocław, $304 \mathrm{pp}$.

GrabDA-KaZUBSKA, B. (1972b): Pleurogenes hepaticola sp. n. (Trematoda, Pleurogenidae), a parasite of the bilary duct of Rana esculenta L. in Poland. Acta Parasit. Polon., 20: $45-54$

GRABDA-KAZUBSKA, B. (1978): Strongyloides spiralis sp.n. (Nematoda, Strongyloididae), a parasite of Rana esculenta s. 1. in Poland. Acta Parasitol. Polon., 25: 235 - 242

GraBDA-KAZUBSKA, B. (1980): Opisthodiscus diplodiscoides Cohn, 1904 (Trematoda, Diplodiscidae) in Rana esculenta s.1. in Poland with remarks on its synonymy and geographical distributions. Acta Parasitol. Polon., 27: 145 $-151$

GRABDA-KAZUBSKA, B. (2000): Parasitic helminths. In: Razowski J. (Ed.). The Flora and fauna of Pieniny Mountains. Volume 1. Monografie Pienińskie, pp. 81 - 85

GraBDA-KAZUBSKA, B., LEWIN, J. (1989): The helminths fauna of Bombina bombina (L.) and B. variegata (L.) in Poland. Acta Parasitol. Polon., 34: 273 - 279

GRAF, J., POLlS-PElAZ, D. M. (1989): Evolutionary genetics of the Rana esculenta hybrid complex. In: Dawley, R., Bogart J (Eds.). Evolution and ecology of unisexual vertebrates. New York State Museum, Albany, NY, pp. 289 - 302 Grossman, T., SANDNER, H. (1954): Helminth fauna of reptilies of Białowieża National Park. Acta Parasitol. Polon., 1: $345-352$

Grossman-PojmańsKa, T., SANDNER, H. (1958): Nowe stanowisko Codonocephalus urnigerus (Rudolphi, 1819) (Trematoda: Strigeidae) w Polsce. Acta Parasitol. Polon., 6: $387-391$

GutTowA, A. (1965): The review of brackish-waters studies in Poland. The studies of plankton of Lake Łebsko and Lake Sarbsko. Pol. Arch. Hydrobiol., 3: 269 - 290

KOZŁOWSKA, J. (1960): On the nematodes of amphibians of Poland, mainly from the environment of Łódź. Acta Parasitol. Polon., 8: 215 - 230

KUC I., SulgostowsKa, T. (1988b): Helminth fauna of frogs in the Forest of Kampinos near Warszawa. Acta Parasitol. Polon., 33: $267-272$

Kuc, I., SulgostowsKa, T. (1988a): Helminth fauna of Rana ridibunda Pallas 1771 from Gocławski Canal in Warszawa (Poland). Acta Parasitol. Polon., 33: 267 - 272. LAYMAN, E. M. (1933): Parasitic worms of fishes of Lake Baikal. Trudy Baikalskoy Limnologicheskoy Stantsii, 4: 5 99 (In Russian)

LEWIN, J. (1992): Parasites of sand lizard (Lacerta agilis
L.) in Poland. Acta Parasitol. Polon., 37: $19-24$

LEWIN, J., GRABDA-KaZUBSKA J. (1997): Parasites of Vipera berus L. in Poland. Acta Parasitol. Polon., 42: 92 - 96

MADEL, G. (1983): Parasites of frogs (Rana esculenta, $R$. temporaria) In. BOCKELER W., WIILKER, E. (Eds.): Parasitologisches Praktikum. Verlag Chemie, Studium Biologie, Weinchein, pp. 1-6

NiEWIAdOMSKA, K. (2003): Guide of Parasites in fishes of Poland - Digenea. Polskie Towarzystwo Parazytologiczne, Warszawa, $169 \mathrm{pp}$.

ODENING, K. (1955/56): Die Zooparaziten der Frösche Deutschlands. Wissenschft. Zeits. F. Schiller. Univ. Jena. Nat. Naturwiss. Reihe, 5: $179-215$

ODENING, K. (1957): Die Helminthenfauna ostthüringer Rana esculenta (L.) Zentralbl. Bakter., 169: 288 - 304

OGIELSKA, M., KIERZKOWSKI, P., RYBACKI, M. (2004): DNA content and genome composition of diploid and triploid water frogs belonging to the Rana esculenta complex (Amphibia, Anura). Can. J. Zool., 82: 1894 - 1901. DOI: $10.1139 /$ Z04-188

PAUL, D. (1934): Beobachtungen über die Darmparasiten schlesischer Anuren, Zschr.f. Parask., 7: 172 - 197

PILECKA-RAPACZ, M. (1997): Preliminary parasitological survey of the representatives of the family Ranidae of Polish Pomerania. In Abstract of Communications of $X^{\text {th }}$ Wrocław Parasitological Conference, 11 - 14. June 1997, Karpacz, Poland: p. 41

PILECKA-RAPACZ, M. (1998): Parasite fauna of alimentary tracts of frogs of the family Ranidae from Polish Western Pomerania. Wiadom. Parazyt., 44: 485

PlasoTA, K. (1969): The effect of some ecological factors on the parasitofauna of frogs. Acta Parasitol. Polon., 16: $47-60$

PlÖTNER, J. (2005): Die Westpaläarktischen Wasserfrösche. Beiheft Z. Feldherp. 9, Laurenti, Bielefeld, 160 pp.

PojMańsKa, T., NiEWIAdOMSKA, K., OKulewicz, A. (2007): Parasitic helminths of Poland. Species. Hosts. White spots. Polskie Towarzystwo Parazytologiczne, Warszawa, $360 \mathrm{pp}$.

PopiołeK, M., WitKowski, A., Kotusz, J., KuszNierz, J., BALDY, K. (2004): Intestinal parasites of brown trout (Salmo trutta fario L.) from streams of the Stołowe Mountains National Park. Parki Nar. Rez. Przyr., 23: 121-127

RYBACKI, M., BERGER, L. (2001): Types of water frog populations (Rana esculenta complex) in Poland. Zoosystem. Evol., 77: 51 - 57. DOI: 10.1002/mmnz.20010770109 SANDNER, H. (1949): Contribution a la connaissance de la faune parasitaire des Batraciens des environs de Varsovie. Acta Zool. et Oecol., Univ. Lodzen., 2: 1 - 28

SinICYN, D. F. (1905): Studies on the life-cycle of trematodes. The distomes of the fishes and frogs in the environs of Warsaw. Mem. Soc. Nat. Varsovie, Biol., 15: 1 $-210$

SochA, M., OGIElSKA, M. (2010): Age structure, size and growth rate of water frogs from central European natural $P e$ lophylax ridibundus - Pelophylax esculentus mixed populations estimated by skeletochronology. Amphibia-Reptilia, 31: 239 - 250. DOI: 10.1163/156853810791069119 
Strzelecki, J., PóŁtorak, T. (1971): The plankton of Lake Gardno near Baltic Sea during the summer season. Acta Hydrobiol., 13: 269 - 294

STYCZYŃSKA, E. (1958): Acanthocephala of the biocenosis of the Drużno Lake (Parasitofauna of the biocenosis of the Drużno Lake - part VI). Acta Parasitol. Polon., 6: 195 - 211 SulgostowsKa, T. (1997): Catalogue of parasite fauna of Poland. IV. Parasites of birds. Acanthocephala. Polskie Towarzystwo Parazytologiczne, Warszawa, 29 pp.

SzULC, W. (1962): Trematodes (Trematoda) of reptilies of the Łódzka Upland. Frag. Faun., 10(7): 99 - 114

VoJTKOVA, L. (1974): Trematoda of amphibians of the CSSR. I. Adult Trematodes. Folia Fac. Sci. Nat. Univ. Purk. Brun., 15: 3 - 131

VoJTKOVA, L. (1975): The importance of the Amphibia for the life- cycle of the Trematoda. Scripta Fac. Sci. Nat. Univ. Purk. Brun., 2 (5): 127 - 136
VoJTKOVA, L. (1989). The occurrence of the representatives of the class Monogenea in amphibians in Europe. Scripta Fac. Sci. Nat. Univ. Purk. Brun., 19: $331-338$

VoJTKOVA, L., RocA, V. (1993): Parasites of the frogs and toads in Europe. Part I: Protozoa, Rev. Esp. Herp., 7: 37 - 45 VojtKova, L., RocA, V. (1994): Parasites of the frogs and toads in Europe. Part II: Trematoda. Rev. Esp. Herp., 8: 7 - 18 VojtKova, L., RocA, V. (1996): Parasites of the frogs and toads in Europe. Part III: Nematoda, Cestoda, Acanthocephala, Hirudinea, Crustacea and Insecta. Rev. Esp. Herp., 10: $13-27$

VojtKova, L., VoJTeK, J. (1975): Trematoda of Amphibians of the CSSR. II. Larval stages of Trematodes. Folia Fac. Sci. Nat. Univ. Purk. Brun., 16: $71-84$ 